\title{
Epidemiological Profile of COVID-19 in Brazil and Worldwide
}

\author{
Carla de Freitas ${ }^{1}$, Gabriela Calanca ${ }^{2}$, Elias Jirjoss Ilias ${ }^{3}$, Arthur Sousa Bezerra ${ }^{4}$ \\ ${ }^{1}$ Universidade Santo Amaro, Brazil \\ Email: cmfreitas013 [AT] gmail.com \\ ${ }^{2}$ Universidade Santo Amaro, Brazil \\ Email: gabicalanca [AT] gmail.com \\ ${ }^{3}$ Universidade Santo Amaro, Brazil \\ Email: eliasjilias [AT] gmail.com \\ ${ }^{4}$ Universidade Santo Amaro, Brazil \\ Email: asbezerra90 [AT] gmail.com
}

\begin{abstract}
---
Introduction: COVID-19, caused by the new coronavirus or SARSCoV-2, has a high capacity for dissemination, which brings about an emergency scenario in public health. It manifests itself in a multifaceted manner, with a great variability in the profile of the affected population, which may be associated with biological, social and economic factors.

Objective: To know the epidemiological profile of the population affected by COVID-19, in order to promote better assistance.
\end{abstract}

Methods: This is a literature review, starting in 2020, using the SciELO, PubMed, Google Scholar, DATASUS databases and the website of the Brazilian Institute of Geography and Statistics (IBGE).

Results: Studies show a higher prevalence of SARS-CoV-2 infection in men, in the age group after the fourth decade of life and among whites.

Discussion: The first studies showed a prevalence of coronavirus infection in males. One of the hypotheses drawn was that men present more cardiopulmonary diseases and smoke more. Another study shows that women's lower susceptibility to infection is due to the $X$ chromosome and sex hormones, which are essential for the innate and adaptive immune response. As for the age group, most studies show a higher prevalence after the fourth decade of life, due to increased expression of angiotensin 2 receptors (ACE2), hormonal changes in aging and associated comorbidities.

Conclusion: Studies show with greater assertiveness a predominance of involvement by COVID-19 in males, individuals from the fourth decade of life and in whites. However, it is important to investigate the epidemiological profile in order to offer better assistance and prevention.

Keywords--- Sex, ethnicity, epidemiological profile, age groups, COVID-19

\section{INTRODUCTION}

Coronavirus is a family of ribonucleic acid (RNA) viruses capable of infecting humans and animals, which can cause respiratory, gastrointestinal, hepatic and neurological changes. In December 2019, in the city of Wuhan, China, an outbreak of patients with pneumonia with a high potential for seriousness and with no determined origin was reported. ${ }^{1,2}$ In January 2020 , the causative virus, named coronavirus or SARS-CoV-2, was identified, with high dissemination capacity, which brought about a public health emergency scenario, being recognized as a pandemic state by the World Health Organization in March 2020. From then on, the disease is now called COVID-19. ${ }^{3}$

The manifestations of COVID-19 vary from asymptomatic, mild, moderate, severe and fulminant cases. ${ }^{2}$ The main and first symptoms described are associated with the respiratory system, such as cough, dyspnoea, fever and fatigue. However, a huge range of symptoms associated with other body systems are also present, such as diarrhea, nausea, abdominal pain, headache, gastrointestinal bleeding. ${ }^{1}$ 
The probable pathophysiology of SARS-CoV-2 infection occurs through viral binding to the angiotensin 2 receptor (ACE2), an extracellular membrane receptor expressed in epithelial cells. ${ }^{4}$ ACE2 is present mainly in tracheobronchial and alveolar cells, as well as in organs of the gastrointestinal tract, such as stomach, duodenum and rectum, which allows the viral colonization of these organs and the appearance of manifestations. ${ }^{5}$

COVID-19 manifests itself in a multifaceted manner, there is enormous variability in the affected population profile, which may be associated with biological, social and economic factors. For example, studies suggest that COVID-19 mainly affects older individuals with multiple comorbidities, such as hypertension, diabetes mellitus, obesity and chronic lung disease. Other research has shown that women were less likely to acquire the virus, as well as less inflammatory cytokine production. ${ }^{1}$ Therefore, knowing the epidemiological profile of the population affected by this disease is essential for better care and prevention.

\section{OBJECTIVE}

To know the epidemiological profile of the population affected by COVID-19, in order to promote better patient care.

\section{METHODS}

This is a narrative review study, starting in the year 2020, using the SciELO, PubMed and Google Scholar databases. The DATASUS electronic database and the website of the Brazilian Institute of Geography and Statistics (IBGE) were also used. In total, 40 articles were analyzed and 17 articles were selected for the study. For the search, the terms "sex", "Ethnic Groups" and "COVID-19" were used.

The inclusion criteria used in the selection of articles were: (1) Objectivity and specificity of the topic addressed; (2) Time since publication, in order to use the most recent ones - starting in 2020. The criteria for exclusion of articles were: (1) Little relevance of the bibliographic reference; (2) case reports.

The types of study selected were: retrospective observational study, multicenter retrospective cohort study and crosssectional descriptive cross-sectional study. All information pointed out in the articles was analyzed and eligible after verification for veracity and updating.

\section{RESULTS}

In the present study, a narrative review of the literature of works was carried out that brought information regarding the incidence of COVID-19 related to sex, color/race and age group.

Table 1. Incidence of contamination by COVID-19 according to female and male

\begin{tabular}{|c|c|c|c|}
\hline Author, country & Number of patients & Female (\%) & Male (\%) \\
\hline Li et al. ${ }^{3}$, China & 1994 & $40 \%$ & $60 \%$ \\
\hline Mo et al. ${ }^{6}$, China & 155 & $44 \%$ & $56 \%$ \\
\hline Xu et al. ${ }^{7}$, China & 133 & $42 \%$ & $58 \%$ \\
\hline${\text { Korean Society of Infectious Diseases et al. }{ }^{8} \text {, South Korea }}$ & 4212 & $62,3 \%$ & $37,7 \%$ \\
\hline Jia et al. $^{9}$, China & 44 & $66 \%$ & $34 \%$ \\
\hline Mizumoto et al. ${ }^{10}$, Japan & 634 & $49 \%$ & $51 \%$ \\
\hline Duarte and cols. ${ }^{11}$, Brazil & 184 & $59,8 \%$ & $40,2 \%$ \\
\hline DATASUS ${ }^{12}$, Brazil & 60030 & $44,8 \%$ & $55,2 \%$ \\
\hline
\end{tabular}


Table 2. Incidence of contamination by COVID-19 according to color/race

\begin{tabular}{|l|l|l|l|l|l|l|l|}
\hline Author (Brazil) & Total & White & Parda & Black & Yellow & Indigenous & Ignored \\
\hline Duarte et al. $^{10}$ & 184 & $40,2 \%$ & $17,4 \%$ & $4,4 \%$ & $1,1 \%$ & $0,5 \%$ & $36,4 \%$ \\
\hline DATASUS $^{12}$ & 53356 & $45,8 \%$ & $24,2 \%$ & $6 \%$ & $2 \%$ & $0,1 \%$ & $21,9 \%$ \\
\hline $\begin{array}{l}\text { Author } \\
\text { (USA) }\end{array}$ & Total & Caucasian & $\begin{array}{l}\text { African- } \\
\text { american }\end{array}$ & Hispanic & Asian & $\begin{array}{l}\text { Indian-american/Alaska } \\
\text { Native }\end{array}$ & Ignored \\
\hline Garg et al. $^{13}$ & 580 & $45 \%$ & $33 \%$ & $8 \%$ & $5 \%$ & $1 \%$ & $7,9 \%$ \\
\hline
\end{tabular}

Table 3. Cases of COVID-19 contamination according to the most prevalent age group, in decades

\begin{tabular}{|l|l|l|}
\hline Author, country & Number of patients & Age group \\
\hline Li et al. ${ }^{3}$, China & 1990 & $5^{\text {th }}$ decade \\
\hline Mo et al. ${ }^{6}$, China & 155 & $5^{\text {th }}$ decade \\
\hline Xu et al. ${ }^{7}$, China & 133 & $5^{\text {th }}$ decade \\
\hline Korean Society of Infectious Diseases et al. ${ }^{8}$, South Korea & 4212 & $2^{\text {nd }}$ decade (religious community) \\
\hline Jia et al. $^{9}$, China & 44 & $4^{\text {th }}$ decade \\
\hline Mizumoto K et al. ${ }^{10}$, Japan & 634 & $6^{\text {th }}$ decade \\
\hline Duarte et al. ${ }^{11}$, Brazil & 184 & $4^{\text {th }}$ decade \\
\hline DATASUS ${ }^{12}$, Brazil & 60030 & $6^{\text {th }}$ decade \\
\hline
\end{tabular}

\section{DISCUSSION}

The first cases of COVID-19 were described in China, so the first studies carried out in this region showed a prevalence of coronavirus infection in males, as the studies by $\mathrm{Li}$ et $\mathrm{al}^{3}$, Mo et $\mathrm{al}^{6}$ and $\mathrm{Xu}$ et $\mathrm{al}^{7}{ }^{7}$ One of the hypotheses made in these studies was that men have a higher prevalence of cardiopulmonary diseases and a higher frequency of smoking. It has also been reported that men have more systemic inflammation, multiple organ failure and heart damage. ${ }^{1}$

Previous clinical studies infer that the female population is less susceptible to viral infections, displays less cytokine production and greater activity of macrophages and neutrophils. In addition, in vivo studies have shown greater expression of the angiotensin-converting enzyme 2 (ACE2) in the kidneys of male patients when compared to female patients. These characteristics can explain the differences in susceptibility and disease progression according to sex. ${ }^{1} \mathrm{~A}$ study by Li et al. shows that the lower susceptibility in females may be associated with the $\mathrm{X}$ chromosome and sex hormones, which would be essential for the innate and adaptive immune response. ${ }^{3}$

Some authors report that the allele responsible for encoding ACE2 is located on the X chromosome, and it can be regulated by the concentration of sex hormones. The increase in estrogen concentration reduces the expression of ACE2 receptors, which enhances neutrophil activity, macrophages and dendritic cells, as well as the humoral and cellular response. ${ }^{1,14}$ The differing immune response between the sexes through hormonal stimulation has already been seen in other viral infections, such as influenza, MERS-CoV and SARS-CoV-1.,13,15

A survey carried out in South Korea brought a higher prevalence of infection in females and one possible explanation was the difference between the social activities of this community, whose religious practice may have contributed to the greatest contamination. ${ }^{1,8}$ That is, the difference between the higher prevalence of COVID-19 infection is associated not only with biological factors, but also with socio-cultural factors in each population. 
In Brazil, according to the study by Duarte et $\mathrm{al}^{11}$, a survey conducted with health professionals, the prevalence of infection was in women, which can be justified by the predominance of women dedicated to these activities. On the other hand, data from DATASUS in the state of São Paulo shows the male sex as the most affected by the disease. ${ }^{11,12}$

Despite the differences presented regarding the prevalence between the sexes, most studies still show the male sex as the most affected, as well as being responsible for the most serious cases of SARS-CoV-2 infection.

The Brazilian population is marked by great miscegenation, which may be associated with a greater predisposition to contamination by the new coronavirus, unlike countries like China, South Korea and Japan, whose predominant race/color of the population is yellow. According to the IBGE's National Household Sample Survey (PNAD), in 2019, 42.7\% of Brazilians declared themselves as white, $46.8 \%$ as pardo, $9.4 \%$ as black and $1.1 \%$ as yellow or indigenous. ${ }^{16}$ The data from the studies by Duarte et $\mathrm{al}^{11}$ and DATASUS ${ }^{12}$, when compared with the IBGE data, show discrepancies regarding the brown population, since it represents about $1 / 4$ of the affected population and about $50 \%$ of the Brazilian population declares itself as pardo. Such dissociation can be explained by the large number of cases in which the color/race was ignored in the counting of contaminated by COVID-19.

However, studies in the United States have shown that ethnic minorities are at increased risk of infection due to the comorbidities associated with them, such as hypertension in African Americans, as well as the higher density of the population with low socioeconomic status. The percentage of African Americans affected in one of the studies was 33\% and they are responsible for only $14.6 \%$ of the country's population. ${ }^{13,17}$

As for the age group, a South Korean study brought a higher prevalence in the group of the second decade of life, which can be explained by the religious and social activities of South Korea. ${ }^{1,8}$ However, most studies show a higher prevalence from the fourth decade of life, which can be explained by the increased expression of ACE2 receptors by the human body due to hormonal changes resulting from aging and associated comorbidities, such as systemic arterial hypertension and diabetes mellitus. In women there is a drop in the hormonal level of estrogen, which compromises their role in reducing the expression of ACE2, as well as in maintaining a greater immune response through a viral infection. ${ }^{1,14}$

\section{CONCLUSION}

Studies show more assertively a higher prevalence of SARS-CoV-2 infection in the male population and in individuals starting from the fourth decade of life. Among the population studied, contamination was higher among whites. A series of justifications was raised in order to explain the epidemiological profile prevalent in the population, although there are still variants of involvement. However, it is still important to investigate the epidemiological profile in order to offer better assistance and prevention.

\section{REFERENCES}

1. Kopel J, Perisetti A, Roghani A, et al. Racial and Gender-Based Differences in COVID-19. Front Public Health. 2020;8:418. PMID: 32850607; https://doi.org/10.3389/fpubh.2020.00418.

2. Wu D, Wu T, Liu Q, Yang Z. The SARS-CoV-2 outbreak: what we know. Int J Infect Dis. 2020;94:44-8. PMID: 32171952; https://doi.org/10.1016/j.ijid.2020.03.004.

3. Li LQ, Huang T, Wang YQ, et al. COVID-19 patients' clinical characteristics, discharge rate, and fatality rate of meta-analysis. J Med Virol. 2020;92(6):577-83. PMID: 32162702; https://doi.org/10.1002/jmv.25757.

4. Rothan HA, Byrareddy SN. The epidemiology and pathogenesis of coronavirus disease (COVID-19) outbreak. J Autoimmun. 2020;109:102433. PMID: 32113704; http://doi.org/10.1016/j.jaut.2020.102433.

5. Eder P, Łodyga M, Dobrowolska A, Rydzewska G, Kamhieh-Milz J. Addressing multiple gastroenterological aspects of COVID-19. Pol Arch Intern Me. 2020;130(5):420-30. PMID: 32356641; https://doi.org/10.20452/pamw.15332.

6. Mo P, Xing Y, Xiao Y, et al. Clinical characteristics of refractory COVID-19 pneumonia in Wuhan, China. Clin Infect Dis. 2020. PMID: 32173725; http://doi.org/10.1093/cid/ciaa270.

7. Xu K, Chen Y, Yuan J, et al. Factors associated with prolonged viral RNA shedding in patients with Coronavirus Disease 2019 (COVID-19). Clin Infect Dis. 2020;71(15):799-806. PMID: 32271376; http://doi.org/10.1093/cid/ciaa351.

8. Korean Society of Infectious Diseases; Korean Society of Pediatric Infectious Diseases; Korean Society of Epidemiology; Korean Society for Antimicrobial Therapy; Korean Society for Healthcare-associated Infection Control and 
Prevention; Korea Centers for Disease Control and Prevention. Report on the epidemiological features of coronavirus disease 2019 (COVID-19) outbreak in the Republic of Korea from January 19 to March 2, 2020. J Korean Med Sci. $2020 ; 35(10):$ e112. PMID: 32174069; http://doi.org/10.3346/jkms.2020.35.e112.

9. Jia J, Hu X, Yang F, et al. Epidemiological Characteristics on the Clustering Nature of COVID-19 in Qingdao City, 2020: A Descriptive Analysis. Disaster Med Public Health Prep. 2020;14(5):643-7. PMID: 32228732; https://doi.org/10.1017/dmp.2020.59.

10. Mizumoto K, Kagaya K, Zarebski A, Chowell G. Estimating the asymptomatic proportion of coronavirus disease 2019 (COVID-19) cases on board the Diamond Princess cruise ship, Yokohama, Japan, 2020. Euro Surveill. 2020;25(10):2000180. PMID: 32183930; http://doi.org/10.2807/1560-7917.ES.2020.25.10.2000180.

11. Duarte MMS, Haslett MIC, Freitas LJA, et al. Descrição dos casos hospitalizados pela COVID-19 em profissionais de saúde nas primeiras nove semanas da pandemia, Brasil, 2020 [Description of COVID-19 hospitalized health worker cases in the first nine weeks of the pandemic, Brazil, 2020]. Epidemiol Serv Saude. 2020;29(5):e2020277. PMID: 32997079; http://dx.doi.org/10.1590/s1679-49742020000500011.

12. TabNet Tecnologia DATASUS. COVID19 Síndrome Respiratória Aguda Grave (SRAG). 2020. Available from: http://tabnet.saude.prefeitura.sp.gov.br/cgi/deftohtm3.exe?secretarias/saude/TABNET/RSRAG/sragh.def. Accessed in 2021 (Feb 15).

13. Garg S, Kim L, Whitaker M, et al. Hospitalization rates and characteristics of patients hospitalized with laboratoryconfirmed coronavirus disease 2019 - COVID-NET, 14 states, March 1-30, 2020. MMWR Morb Mortal Weekly Rep. 2020;69(15):458-64. PMID: 32298251; https://doi.org/10.15585/mmwr.mm6915e3.

14. Scully EP, Haverfield J, Ursin RL, Tannenbaum C, Klein SL. Considering how biological sex impacts immune responses and COVID-19 outcomes. Nat Rev Immunol. 2020;20(7):442-7. PMID: 32528136; https://doi.org/10.1038/s41577020-0348-8.

15. ten-Caten F, Gonzalez-Dias P, Castro I, et al. In-depth Analysis of Laboratory Parameters Reveals the Interplay Between Sex, Age and Systemic Inflammation in Individuals with COVID-19. 2020. https://doi.org/10.1101/2020.08.07.20170043.

16. Azevedo A. IBGE - Educa Jovens. 2020. Available from: https://educa.ibge.gov.br/jovens/conheca-obrasil/populacao/18319-cor-ouraca.html. Accessed in 2021 (Feb 05).

17. Shah M, Sachdeva M, Dodiuk-Gad R. COVID-19 and racial disparities. J Am Acad Dermatol. 2020;83(1):e35. PMID: 32305444; https://doi.org/10.1016/j.jaad.2020.04.046. 